\title{
Efficiency of Slow Release Fertilizers in The Production of Eucalyptus Grandis Seedlings
}

\author{
Fernanda Leite Cunha ${ }^{1}$ (1) \\ Erick Martins Nieri ${ }^{2}$ (D) \\ Lucas Amaral de Melo ${ }^{1}$ \\ Evandro Nunes Miranda ${ }^{1}$ (D) \\ Tales Jesus Fernandes ${ }^{3}$ (D) \\ Nelson Venturin ${ }^{1}$ (D) \\ ${ }^{1}$ Universidade Federal de Lavras, Ciências Florestais, Lavras, MG, Brasil. \\ ${ }^{2}$ Universidade Federal do Sul e Sudeste do Pará, São Félix do Xingu, Pará, PA, Brasil. \\ ${ }^{3}$ Universidade Federal de Lavras, Departamento de Estatística, Lavras, MG, Brasil.
}

\begin{abstract}
Fertilization in the seedling production phase is essential to form quality seedlings. Thus, the aim of this study was to evaluate the appropriate doses of two slow-release fertilizers (SRF1 and SRF2) and their nutrient leaching behavior. For this, five different doses of fertilizers were tested. $0,2,4,6$, and $8 \mathrm{~kg} \mathrm{~m}^{-3}$. The height, stem diameter, leaf area, shoot dry mass, root system dry mass, total dry mass, and the Dickson Quality Index were measured, and for each variable the maximum dose of technical efficiency was determined. In addition, was evaluated the electrical conductivity, over time, for determinate the leaching of the nutrients. All the variables had satisfactory growth for field planting. However, the SRF2 resulted in greater seedling growth and also experienced less nutrient loss by leaching, when compared with the SRF1. The both fertilizers could be utilized to seedlings production, at doses of $4.00 \mathrm{~kg} \mathrm{~m}^{-3}$.
\end{abstract}

Keywords: forest nutrition; controlled fertilization; fertilizer leaching.

\section{INTRODUCTION}

The use of quality seedlings is essential to guarantee the success and establishment of forest stands, as it can increase their survival and post-planting growth, thus reducing the need for replanting and maintenance (Silva et al., 2015). Quality seedlings must have a good nutritional status, to ensure their vigor and that they have the characteristics necessary for planting.

Slow release fertilizers (SRF) can be used for the production of seedlings, as they both gradually and continuously release nutrients, and consequently reduce fertilizer losses from leaching and volatilization (Dinali et al., 2012). This is considered a major advance, since the main loss of nutrients in seedling production systems in uncovered nurseries, is due to excessive irrigation and rain (Da Ros et al., 2017). Furthermore, their use can reduce labor and energy costs, and damage to seeds or seedlings owing to the salinity of culture mediums, in addition to maintaining a synchronization of nutrient release with the growth and development needs of the plants (Yamamoto et al., 2016).

In Brazil, the production of slow-release fertilizers for forest seedlings is dominated by two manufacturers, who distinguish their products by the composition of their organic polymer coatings, one being an alkyd resin and the other an elastic polymer Poligen (Brodani et al., 2008, Davide et al., 2015, Simão, 2017). According to Brachtvogel \& Malavasi (2010), increasing the doses of the SRF coated with alkyd resin $(\mathrm{N}$ : P: K, 14:14:14) for the production of forest seedlings, resulted in higher quality seedling production. Rossa et al. (2011) and Serrano et al. (2010), observed that there was also a significant effect from the use of increasing doses of SRF coated with the Poligen polymer (N: P: K, 13:06:16), for the production of forest species seedlings (Araucaria angustifolia and Ocotea odorifera) and agronomic seedlings (Carica papaya, papaya). 
Due to the possible advantages of using slow-release fertilizers, there have been numerous investigations that have aimed to improve and develop the technology behind them. These investigations, with their objective being to obtain formulations that meet the nutritional demands of several species, have resulted in the more efficient release of nutrients and lower production costs (Chawakitchareon et al., 2016; Chen et al., 2018). New technologies for slowrelease fertilizers include those for their encapsulation with elemental sulfur, coating them with non-water-soluble organic polymers, and formulations that are compatible with the production of seedlings.

Despite efforts to produce different types of SRF, the loss of nutrients in the percolated water from tubes, is a seedling production parameter in automated irrigation systems that has not been widely examined (Da Ros et al., 2017). The aim of this investigation was to evaluate the quality of seedling production, when using slow release fertilizers, in order to: a) evaluate the appropriate doses for SRF encapsulated with elemental sulfur and coated with non-water-soluble organic polymers, in comparison to SRF coated with alkyd resin organic polymers, which commonly used to produce forest seedlings; and $b$ ) to evaluate the loss of the fertilizers over time via leaching, during the production of Eucalyptus grandis seedlings.

\section{MATERIALS AND METHODS}

The experiments were installed and conducted in the forest nursery in the southern region of Minas Gerais, Brazil $\left(21^{\circ} 13^{\prime} 14.033^{\prime \prime S}\right.$ and $\left.44^{\circ} 58^{\prime} 0.232^{\prime \prime} \mathrm{O}\right)$. The regions' climate was classified according to Köppen's proposal, as $\mathrm{Cwb}$ which indicates a dry winter subtropical highland climate with mild summers (Alvares et al., 2013).

The seedlings were produced from April to October, in 2019 , with an average temperature of $28.31^{\circ} \mathrm{C}$, an average monthly minimum rainfall of $8.6 \mathrm{~mm}$, and a maximum monthly rainfall of $190.2 \mathrm{~mm}$. Seeds were collected from a stand of Eucalyptus grandis in the south of Minas Gerais, and were sown in tubes that were $55 \mathrm{~cm}^{3}$. The seedlings remained in the shade house for 50 days, with $50 \%$ irradiance, and micro-sprinkler irrigation three times a day for five minutes each, at a flow rate of $140 \mathrm{~L} \mathrm{~h}^{-1}$. They were then transferred to full sun for rusting where they were irrigated four times a day for five minutes each, at a flow rate of $95 \mathrm{~L} \mathrm{~h}^{-1}$.

The treatments consisted of two types of slow-release fertilizers. SRF1 is characterized as being encapsulated with elemental sulfur and coated with non-water-soluble organic polymers. This fertilizer releases nutrients from four to six months after application, and has a formulation of $10 \% \mathrm{~N}$, $15 \% \mathrm{P}_{2} \mathrm{O}_{5}, 20 \% \mathrm{~K}_{2} \mathrm{O}, 8.64 \% \mathrm{~S}, 0.39 \% \mathrm{~B}, 0.39 \% \mathrm{Cu}$, and 0.39 $\% \mathrm{Zn}$. SRF2 is characterized as being coated with an organic polymer, composed of alkyd resin, and is commonly used to produce forest seedlings. The release time of nutrients is four to six months, after application, and it has a formulation of $15 \% \mathrm{~N}, 9 \% \mathrm{P}_{2} \mathrm{O}_{5}, 12 \% \mathrm{~K}_{2} \mathrm{O}, 1.3 \% \mathrm{Mg}, 5.9 \% \mathrm{~S}, 0.46 \% \mathrm{Fe}$, $0.05 \% \mathrm{Cu}, 0.05 \% \mathrm{Mn}$, and $0.02 \% \mathrm{Mo}$.

The substrate used as the base was $50 \%$ commercial Substrate Maxfertil (pine bark, ash, vermiculite, sawdust, and bio-stabilizers), $25 \%$ carbonized rice husk, and $25 \%$ coconut fiber. To homogenize the tested doses to the base substrate, a concrete mixer was used for five minutes.

To answer the objectives of the investigations, it was necessary to conduct two separate experiments. The first experiment evaluated the quality and ideal doses of the SRF1 and SRF2 fertilizers. The experiment was arranged in a 2 $\times 5$ factorial scheme (two types of SRF for five doses), in a completely randomized design (DIC), with four replications, with the plot consisting of 20 seedlings. The slow release fertilizers used were SRF1 and SRF2, at doses of 0, 2, 4, 6, and $8 \mathrm{~kg} \mathrm{dm}^{-3}$.

After 180 days, the height $(\mathrm{H})$ and stem diameter (SD) of the 12 central seedlings of each plot were measured. The heights were measured with the aid of a ruler in $\mathrm{cm}$, from the level of the substrate to the apical bud. The DC was measured at the substrate level using digital calipers with a precision of $0.01 \mathrm{~m}$.

Shoot dry mass (SDM), root system dry mass (RSDM), and total dry mass (TDM) were also evaluated at 180 days. For these evaluations, five seedlings were used per plot, and the material was dried in an oven with forced air circulation, at $75^{\circ} \mathrm{C}$, for 72 hours.

Using the data for the analyzed variables, the morphological indices, i.e., the Robustness Index (H / SD) and Dickson's Quality Index (DQI) (Dickson et al., 1960), were calculated. The DQI was as follows (Equation 1):

$$
D Q I=\frac{T D M}{\frac{H}{S D}+\frac{S D M}{R S D M}}
$$

where, $\mathrm{TDM}=$ total dry mass; $\mathrm{H}=$ height; $\mathrm{SD}=$ stem diameter; $\mathrm{SDM}=$ shoot dry mass; and RSDM = root system dry mas.

Leaf area (LA) was measured after 180 days, using the leaves from four seedlings within each plot assessed. The leaves for each plot were fixed on a white sheet of A4 paper, next to 
a mm ruler. Images were captured with the aid of a digital camera, at a height of $0.5 \mathrm{~m}$. The leaf areas were measured from the digital images, using the public domain software Image (Powerful Image Analysis). Image ${ }^{\ominus}$ software captures the leaf images by means of contrasting colors, as the leaves were a dark color on a contrasting light colored background. To calculate the leaf area the ruler in the images was used as a scalee calculation of the real leaf area, the comparison with a real scale present (Jadoski et al., 2012).

The collected data obtained were submitted to the analysis of normality of errors by the Shapiro-Wilk test with a 5\% probability of error. When checking for normality, an analysis of variance (ANOVA) were performed, and once the significant difference were verified, a media comparison were performed using the Tukey test at a $5 \%$ probability of error for the two fertilizers used, and regression was performed, of media at the level of $5 \%$ probability of error, for the doses used, through the SISVAR software (Ferreire, 2014).

The maximum dose of technical efficiency (MDTE) was calculated for the variables when the $\mathrm{F}$ test, at $5 \%$ probability of error, determined that there was a significant difference. Linear regression analysis of the variables was performed as a function of the fertilizer doses tested, considering the significance of the coefficients, at a $5 \%$ probability of error, and the determination coefficient $\left(\mathrm{R}^{2}\right)$. The MDET, of the variables of interest, corresponded to the first derivative of the adjusted equations equaled to zero. When the calculated value exceeded the maximum tested dose, the MDTE considered was $8 \mathrm{~kg} \mathrm{~m}^{-3}$.

The second experiment was established to assess the leaching of SRF1 and SRF2. For this, an experimental design with a $2 \times 5$ factorial scheme (two types of SRF and five doses of SRF), arranged in a completely randomized design (DIC), with four replications, and plots subdivided over time was used (Steel \& Torrie, 1980).

To quantify the leaching of the fertilizers, the electrical conductivity (EC) of the water solution that percolated over the substrate and was stored in containers that included the tube, was determined. The containers were polyethylene bags, with dimensions of $20 \times 5 \times 0.5 \mathrm{~cm}$, and they were fixed to four seedlings per plot to store the percolated solution. After each evaluation, the solutions in the containers were discarded. Measurements were made every seven days, for 100 days during seedling production, at which time there were no significant variations in the electrical conductivity averages.

The collected data were tabulated and analyzed using ANOVA, and once the significant differences were verified, data regression analysis was performed. In order to observe the leaching behavior, a non-linear Henderson model with two parameters was used (Equation 2) (Henderson \& Pabis 1961), to represent the electrical conductivity (EC) as a function of time in days (Equation 2). Thus, the model was applied to the representative sample without SRF interference (dose of $0 \mathrm{~kg} \mathrm{~m}^{-}{ }^{3}$ ), and for the different fertilizer doses applied in the test $\left(0,2,4,6\right.$, and $\left.8 \mathrm{~kg} \mathrm{dm}^{-3}\right)$.

$$
\mathrm{EC}=\theta_{0} \exp \left(-\theta_{1} \mathrm{t}_{1}\right)+\varepsilon_{j}
$$

where: $\theta_{\mathrm{i}}$ is the estimated parameters; $t_{\mathrm{i}}$ is the independent variable days; $\varepsilon_{\mathrm{i}}$ is the random error.

The coefficient of determination $\left(R^{2}\right)$ and the square root of the mean square error (SRMSE) (Equation 3) were used to verify the accuracy of the adjustments.

$S R M S E=\sqrt{\frac{1}{n} \frac{\left(\widehat{Y_{I}}-Y_{I}\right)^{2}}{n}}$

where, SRMSE is the square root of the mean square error; $\mathrm{n}$ is the number of configurations; $\mathrm{y}_{\mathrm{t}}$ is the mean; and is the estimated average.

\section{RESULTS}

The variables H, LA, SDM, RSDM, TDM, and DQI showed a significant interaction between the types of fertilizers and the doses applied. For these variables, it was observed that the growth of the seedlings fertilized with SRF2 was higher than for those fertilized with SRF1, Figure 1.

The maximum technical doses found for SRF1 and SRF2 were 7.20 and $6.02 \mathrm{~kg} \mathrm{~m}^{-3}$ for $\mathrm{H}, 5.15$ and $8 \mathrm{~kg} \mathrm{~m}^{-3}$ for LA, 8.00 and $8.00 \mathrm{~kg} \mathrm{~m}^{-3}$ for RDM, 7.55 and $6.20 \mathrm{~kg} \mathrm{~m}^{-3}$ for SRDM, 8.00 and $8.00 \mathrm{~kg} \mathrm{~m}^{-3}$ for TDM, and 8.00 and $7.81 \mathrm{~kg} \mathrm{~m}^{-3}$ for the DQI, respectively.

The stem diameter and robustness index (H/SD) (Figure 2) showed significant differences between the fertilizer doses, with MDTEs of 6.67 and $5.85 \mathrm{~mm}$, respectively. The SRF assessments for each fertilizer showed that for the robustness index, there was no significant difference, and the average difference was 9.47 for both fertilizers. As for the diameter of the collection, the SRF2 $(2.50 \mathrm{~mm})$ resulted in greater growth than the SRF1 $(2.07 \mathrm{~mm})$. 

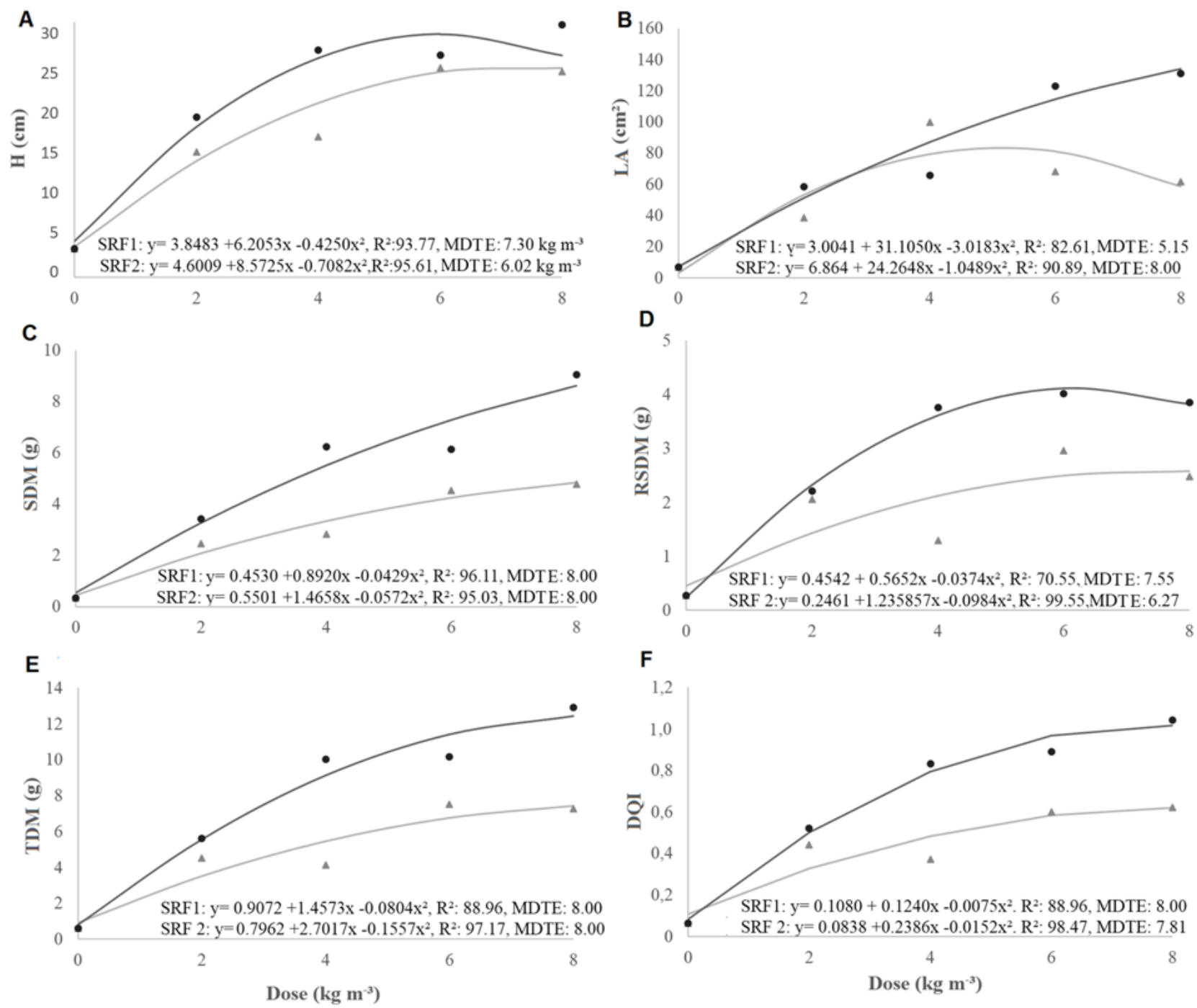

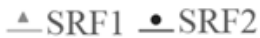

Figure 1. Effects of the fertilizers SRF1 (encapsulated with elemental sulfur and coated with non-water-soluble organic polymers) and SRF2 (coated with organic alkyd resins) doses on the seedling growth and maximum dose technical efficiency (MDTE), for the A: height (H), B: leaf area (AF), C: shoot dry matter (SDM), D: root system dry matter (RSDM), E: total dry matter (TDM), and F: Dickson Quality Index (DQI), in the seedlings of Eucalyptus grandis, after 180 days.

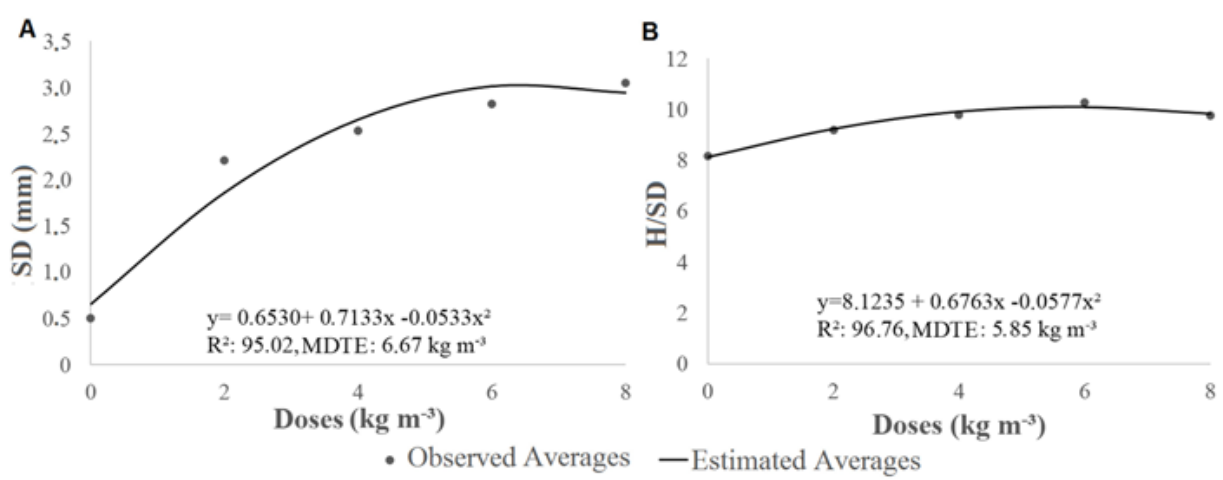

Figure 2. Average effect of the slow realize fertilizer (SRF) doses and their respective maximum technical efficiency doses (MDTE), on the A: stem diameter (SD), and B: robustness index (H/SD) variables, for different doses of SRF1 (encapsulated with elemental sulfur and coated with non-watersoluble organic polymers) and SRF2 (coated with organic alkyd resins), in seedlings of Eucalyptus grandis, after 180 days. 
The parameters used for the adjustment of the electrical conductivity, $\mathrm{R}^{2}$, and SRMSE, are shown in table 1 . The different doses of each fertilizer, the best adjustment obtained was $0 \mathrm{~kg}$ $\mathrm{m}^{-3}$, since this obtained high $\mathrm{R}^{2}$ of $79 \%$, and low SRMSE of $0.0006 \mathrm{~S} \mathrm{~cm}^{-1}$. In general, the adjustment of the doses for both fertilizers was satisfactory, except for the $8 \mathrm{~kg} \mathrm{~m}^{-3}$ dose, as it obtained an $\mathrm{R}^{2}$ of less than $60 \%$.

Figure 3 shows the results of the electrical conductivity for SRF1 and SRF2 over time. The results show that for both fertilizers and for all doses, an inverted jet behavior was obtained, that is, during the irrigation days, there was a reduction in the average electrical conductivity in the collected solutions. SRF1 showed a greater loss of fertilizer compared to SRF2, with an average electrical conductivity that was $46 \%$ higher. The dose with the highest electrical conductivity was $8 \mathrm{~kg} \mathrm{~m}^{-}{ }^{3}$, with $1.8 \mathrm{~S}$ $\mathrm{cm}^{-1}$ for SRF1 and $1.3 \mathrm{~S} \mathrm{~cm}^{-1}$ for SRF2. The dose with the lowest electrical conductivity was $0 \mathrm{~kg} \mathrm{~m}^{-}{ }^{3}$. After 60 days, the averages EC's obtained for the variable, for both fertilizers, were similar.

Table 1. Estimated parameters, for Henderson's nonlinear model, $(\theta 1$ and $\theta 2)$, their determination coefficients $\left(R^{2}\right)$, and the square roots of the mean square error (SRMSE).

\begin{tabular}{|c|c|c|c|c|c|}
\hline Fertilizers & Dose & $\theta_{0}$ & $\theta_{1}$ & $\mathbf{R}^{2}(\%)$ & $\operatorname{RMSE}\left(\mathrm{S} \mathrm{cm}^{-1}\right)$ \\
\hline \multirow{5}{*}{ SR F1 } & 0 & $0.076^{*}$ & 0.011 * & 79.70 & 0.006 \\
\hline & 2 & $0.876^{*}$ & $0.038^{*}$ & 62.00 & 0.231 \\
\hline & 4 & $3.082^{*}$ & $0.037^{\star}$ & 64.40 & 0.160 \\
\hline & 6 & $1.177^{*}$ & $0.029 *$ & 75.50 & 0.292 \\
\hline & 8 & $1.112^{*}$ & $0.020^{*}$ & 69.30 & 0.242 \\
\hline \multirow{5}{*}{ SRF 2} & 0 & $0.076^{*}$ & $0.011^{*}$ & 79.70 & 0.006 \\
\hline & 2 & $1.410^{*}$ & $0.030^{*}$ & 88.00 & 0.065 \\
\hline & 4 & $1.037^{*}$ & $0.028^{*}$ & 76.20 & 0.350 \\
\hline & 6 & $2.641^{*}$ & $0.028^{*}$ & 75.80 & 0.132 \\
\hline & 8 & $1.886^{*}$ & $0.029^{*}$ & 48.00 & 0.210 \\
\hline
\end{tabular}

Where: $\theta_{i}$ indicates the estimated parameters; $\mathrm{R}^{2}$ is the determination coefficient; SRMSE is the mean quadratic standard error. ${ }^{*}$ indicates significance at a $5 \%$ probability level of error.

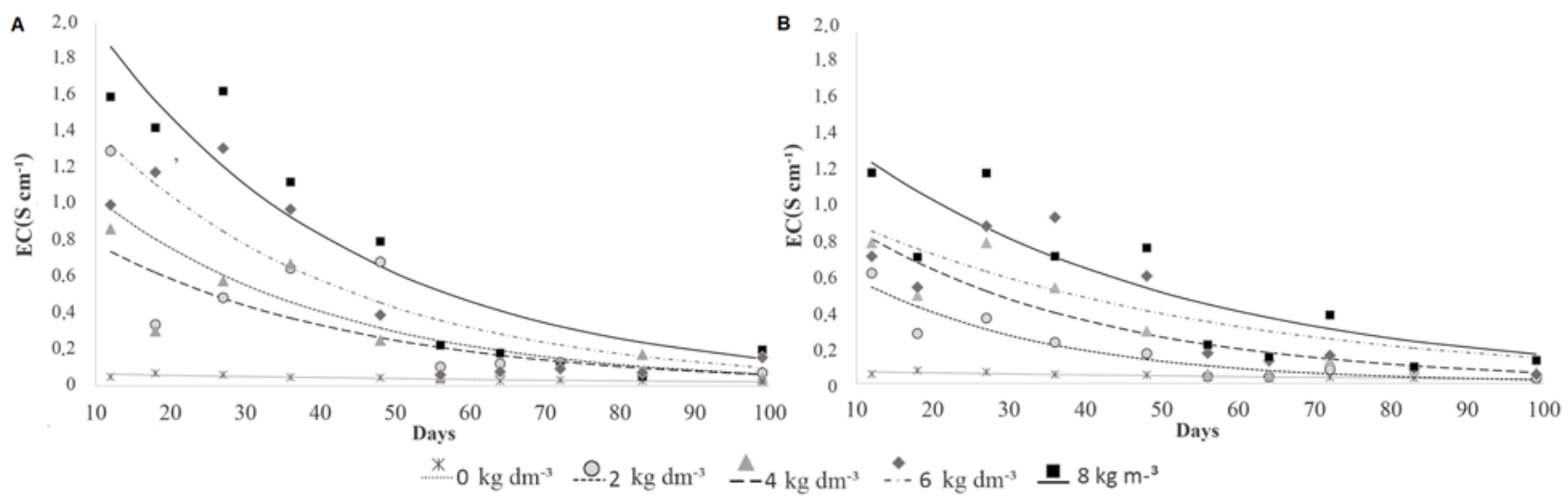

Figure 3. Leaching of SRF1 (A) and SRF2 (B) fertilizers by means of electrical conduction, during the first 100 days of production of Eucalyptus grandis seedlings.

\section{DISCUSSION}

When reviewing the results of this investigation, it was noted that the lowest amounts of growth occurred for the treatments without fertilization, for all variables. 'This confirms that, like the findings of Marschner (2012), Rossa et al. (2015), and Muniz et al. (2013), nutritional complementation is necessary for the good development of seedlings in tubes, regardless of the substrate.
Height is one of the oldest parameters to assess the quality of seedling formation, as it is easy to measure (Navroski et al., 2016). According to the MDTE, the ideal doses for SRF1 and SRF2 were 7.30 and $6.02 \mathrm{~km} \mathrm{~m}^{-3}$, respectively. However, the averages found for eucalyptus from doses of $4 \mathrm{~kg} \mathrm{~m}^{-3}$ were adequate for planting, for both fertilizers, according to Wendling \& Dutra (2010), that recomendated a minimum heigth of $15 \mathrm{~cm}$ for eucalyptus seedling, for planting in field. Similar results were also found for Navorski et al. (2016) and 
Rossa et al. (2015), for Eucalyptus sp. seedlings, using SRF2 and SRF coated with Poligen elastic polymer, respectively, which may indicate, that the dose of $4 \mathrm{~kg} \mathrm{~m}^{-3}$ of SRF is suitable for fertilization of eucalyptus seedlings.

Leaf area is one of the most important variables for plant growth, since it is related to the photosynthetic area (Mendes et al., 2013), and this may explain why the SRF2 seedlings had greater growth as this fertilizer had a higher $\mathrm{N}$ percentage. Furthermore, $\mathrm{N}$ is linked to the synthesis of chlorophyll and the energy system, thus enabling the formation of proteins and the growth of the leaf area (Santos et al. 2019; Dechen; Nachtigall, 2007).

It was noted that the increases in $\mathrm{H}, \mathrm{LA}, \mathrm{RDM}, \mathrm{SRDM}$, $\mathrm{TDM}$, and DQI with the SRF1 were lower than the increases with the SRF2. This is related to the lower N content (10 \%) in the SRF1 formulation, when compared to the $\mathrm{N}$ content (15\%) of the SRF2. Navroski et al. (2016) previously found that specific doses of SRF2 (16:06:10) with Eucalyptus dunnii were found to result in a higher LA, when compared to the two other fertilizers studied, with an MDTE of $5.60 \mathrm{~kg} \mathrm{~m}^{3}$, corresponding to $103.4 \mathrm{~cm}^{2}$, which may be related to the higher percentage of $\mathrm{N}(16 \%)$ in the fertilizer. The lower $\mathrm{N}$ contents in SRF1 and SRF2, may be responsible for the lower values for the other measured variables, such as dry mass, which according to Pinto et al. (2011) is directly related to the leaf area, and is an important and fundamental criterion for the vigor of forest species.

The shoot dry mass is directly related to LA, photosynthetic activity, and carbon allocation to different parts of the plant (Navroski et al., 2016). It is inferred that seedlings with a higher SDM value have a greater capacity to adapt in the field, as they obtain a higher percentage of their essential energy reserves to supply vital needs (Freitas et al., 2012, Reis, 2021). Thus, the ideal doses for the plants to reach the maximum SDM for both fertilizers was determined to be 8.00 $\mathrm{kg} \mathrm{m}^{-3}$, respectively, which was close to the value identified by Mendonça et al. (2008), who obtained an MDTE close to $9 \mathrm{~kg} \mathrm{~m}^{-3}$ for SDM, for Tamarindus indica.

According to Rossa et al. (2015), the use of slow release fertilizers occasionally resulted in greater SDM, SRDM, and TDM, for Eucalyptus grandis seedlings, given the same or lower doses, when compared to the use of formulated, immediate release, and substrate fertilizers. This may be related to the characteristic of gradual release of nutrients, which causes greater recovery of fertilizer by plants, and consequently greater accumulation of biomass and growth (Raymond, Fox \& Strahm, 2016).

The DQI is considered a good indicator of seedling quality, because the robustness index (H/SD) and balance of biomass distribution (SDM/RSDM), that are used for its calculation (Smiderli et al., 2018, Gonzaga et al., 2016, Eloy et al., 2013), involve several important morphological characteristics used for quality assessment. The authors also emphasize that the higher the DQI, the better the quality of the seedling produced. In this investigation the MDTE was found to be $8.26 \mathrm{~kg} \mathrm{~m}^{-3}$ for SRF1 and $7.81 \mathrm{~kg} \mathrm{~m}^{-3}$ for SRF2. The results of this study were superior to those presented by Rossa et al. (2015), who found a maximum DQI of 0.10 with a dose of $8 \mathrm{~kg} \mathrm{~m}^{-3}$, when using the different dosages of SRF2 with the seedlings of Eucalyptus grandis.

The minimum recommended stem diameter for planting in the field, according to Wendling \& Dutra (2010), was 2 $\mathrm{mm}$. Accordingly, the four tested doses $(2,4,6$, and $8 \mathrm{~kg}$ $\left.\mathrm{m}^{-3}\right)$, thus showed appropriate growth. However, Baldin et al. (2015), points out that the larger the stem diameter collected, the greater the survivability and emission of new roots by the seedlings in the field. Thus, the MDTE indicated for this variable was $6.67 \mathrm{~kg} \mathrm{~m}^{-3}$.

The robustness indices (H/SD) of the seedlings were not in accordance with those of Araújo et al. (2018), who determined that the ideal index should be between 5.4 and 8.1. However, it is noted that this range may not be suitable for the genus Eucalyptus sp., since the seedlings showed vigor in the evaluation and were suitable for planting. Simões et al. (2012) and Kratz \& Wedling (2016) also observed an H/SD ratio outside the indicated range, between 9.39 and 12.13 , and a value of 14.04, for seedlings of Eucalyptus camaldulensis, respectively.

In general, the variables showed positive quadratic growth when the doses of SRF1 and SRF2 were increased. Similar behaviors for the same variables described above were observed in the seedlings of Anadenanthera colubrina (Brondani et al., 2008) and Eucalyptus grandis (Rossa et al., 2015), with different doses of maximum technical efficiency, ranging from 1.6 at $2.7 \mathrm{~g} \mathrm{dm}^{-3}$ and 9.1 at $11.8 \mathrm{~g} \mathrm{dm}^{-3}$, respectively.

The electrical conductivity of the SRFs appeared to have inverted jet behavior, that is, the leaching of the fertilizer was greater in the first days of the seedling production cycle, and then reduced over time. This result was like the leaching of nutrients from the slow-release fertilizers, found by Xiaoyu et al. (2013), and Gwenzi et al. (2018). However, this behavior contradicts the SRF release pattern described by Trekel (2010), who reporting that the release occurs in phases, the first being of lesser release (phase 1), followed by a faster release phase (phase 2), and subsequently a total release of nutrients (phase 3 ).

Gwenzi et al. (2018), despite having found an inverted jet behavior, found that the observed points of the leaching of the nutrients showed peaks over time, which is in accordance with out results, of up to 50 days, mainly for the higher doses 
( 6 and $8 \mathrm{~kg} \mathrm{~m}^{-3}$ ), which may correspond to the nutrient release behavior described by Trekel (2010), in phase 2; that is, there are points of greater and faster release of nutrients.

The most growth was found for the eucalyptus seedlings fertilized with SRF2. This was related to the nutrient release and leaching pattern, since all doses of SRF1 in the first days of seedling production showed higher electrical conductivity, that was approximately $46 \%$ higher than that of SRF2. This is not desired, as in this period, according to Oliveira et al. (2012), plants do not yet have a root system developed to absorb nutrients, thus it will result in nutrient losses to the environment through leaching, and reduces seedling growth potential.

The different efficiencies and formulations of the SRF found on the market, emphasizes the need for investigations such as this, to identify the appropriate doses, for the best development of plants. According to Da Ros et al. (2017), adequate attention to the requirements for fertilization are necessary, especially during this era of best nursery management practices, environmental sustainability, and when the loss of nutrients to the environment by the substrate should be avoided. According to the MDTE, the appropriate average doses of SRF1 and SRF2 were $7.71 \mathrm{~kg} \mathrm{~m}^{-3}$ and $8.00 \mathrm{~kg} \mathrm{~m}^{-3}$, respectively. However, it is recommended to use $4 \mathrm{~kg} \mathrm{~m}^{-3}$, since this dose provides seedlings with adequate growth for planting in the field but avoids the use of high doses that can increase the cost of seedling production, in addition to increasing the loss of nutrients to the environment via leaching.

Thus, it was observed that both fertilizers meet the minimum requirements for the growth and quality of seedling production for eucalyptus. However, the use of SRF2 provided greater growth and better-quality seedlings, which can improve their rates of survival and development in the field. The increased growth of the seedlings fertilized with SRF2, may be related to a reduced leaching of the nutrients by the substrate, and its higher nitrogen content.

The loss of nutrients in the percolated water from the tubes (leaching) is a parameter of seedling production that has not previously been widely investigated (Da Ros et al., 2017). However, our results indicate that it is a crucial parameter that needs to be considered when nurseries design fertilizer schedules. The choice of the appropriate fertilizer to use, based on the highest cost benefit, will depend on the established plan, the time of seedling production, the quality of seedling formation, and the cost to purchase each fertilizer.

\section{CONCLUSIONS}

The both fertilizers tested, are efficient for the production of Eucalyptus grandis seedlings at doses of $4.00 \mathrm{~kg} \mathrm{~m}^{-3}$. However the SRF2 use resulted in greater growth of the seedlings, when compared to SRF1.

The SRF1 had the greatest loss of nutrients by leaching to the environment and the greatest leaching of nutrients was detected with doses of $8 \mathrm{~kg} \mathrm{~m}^{-3}$.

\section{SUBMISSION STATUS}

Received: 27 Jul. 2021

Accepted: 30 Sep. 2021

Associate editor: Marcos Gervásio Pereira (1)

\section{CORRESPONDENCE TO}

\section{Fernanda Leite Cunha}

Universidade Federal de Lavras, Departamento de Ciências Florestais Silvicultura, CEP 37200-900, Lavras, MG, Brasil.

e-mail: fernandaleitecunha@gmail.com

\section{AUTHORS' CONTRIBUTIONS}

Fernanda Leite Cunha: Conceptualization (Equal); Data curation (Equal); Formal analysis (Lead); Investigation (Lead); Methodology (Equal); Project administration (Lead).

Erick Martins Nieri: Investigation (Equal); Methodology (Equal); Writing-review \& editing (Equal).

Lucas Amaral de Melo: Supervision (Equal); Writing-review \& editing (Equal).

Evandro Nunes Miranda: Data curation (Supporting); Software (Equal); Validation (Supporting).

Tales Jesus Fernandes: Data curation (Supporting); Validation (Supporting).

Nelson Venturin: Resources (Supporting); Supervision (Lead).

\section{REFERENCES}

Alvares CA. et al. Köppen'sclimateclassificationmap for Brazil. Meteorologische. Zeitschrift, Stuttgart. v. 22, n. 6, p. 711-728, dez. 2013.

Araújo MM, Navrosku MC, Schorn, LA. Produção de sementes e mudas - Um enfoque à silvicultura. 1 ed. Editora UFSM: Universidade Federal de Santa Maria; 2018.

Baldin T, Conte B, Denardi, L, Moraes R, Witt C. Crescimento de mudas de angico-vermelho em diferentes volumes de substratos. Pesquisa Florestal Brasileira, 2015, 35, 31-37.

Brondani GE et al. Fertilização de liberação controlada no crescimento inicial de angico-branco. Scientia Agraria, 2008, 9, 167-176.

Brachtvogel EL, Malavasi, U C. Volume do recipiente, adubação e sua forma de mistura ao substrato no crescimento inicial de Peltophorum dubium (sprengel) taubert em viveiro. Revista Árvore 2012, 34(2), 223-232.

Chawakitchareon, PR, Anuwattana, J. Production of slow release fertilizer from waste materials. Advanced Materials Springer International Publishing 2016, 83(4), 534-540. 
Chen SL, Yang M, Ba C, Yu SS, Jiang YF, Zou HT, Zhang YL. Preparation and characterization of slow-release fertilizer encapsulated by biochar-based waterborne copolymers. Science of the Total Environment 2018, 615, 431- 437.

Davide AC, Melo LA, Teixeira LAF, Prado NJS, Fiorine RA, Carvalho RP. Fatores que afetam a qualidade de mudas destnadas aos projetos de restauração de ecossistemas florestais. In: DAVIDE, A. C.; BOTELHO, S. A. Fundamentos e métodos de restauração de ecossistemas florestais. 1ed, Lavras: Editora UFLA, 2015.

Da Ros CO, Silvestrin TB, Somavilla L, Silva RF, Silva VR. Perdas de Nutrientes por Lixiviação na Produção de Mudas de Cedro Australiano. Floram 2017, 24.

Dinalli RP, Castilho RMM, Gazola RN. Utilização de adubos de liberação lenta na produção de mudas de Vigna radiata L. Revista Cienífica Eletrônica de Agronomia 2012, 21, 10-15.

Dickson A, Leaf A, Hosner JF. Quality appraisal of white spruce and white pine seedling stock in nurseries. Forestry Chronicle 1960, 36, 10- 13.

Dechen AR, Nachtigall GR. Elementos requeridos à nutrição de plantas. In: Novais, R. F. et al. Fertilidade do solo. Viçosa: Sociedade Brasileira de Ciência do Solo 2007.

Ferreira DF. Sisvar: guide for its bootstrap procedures in multiple comparisons. Ciência e Agrotecnologia 2014, 38(2) 109-112.

Eloy E, Caron BO, Schmidt D, Behling, A, SCHWERS L, ELLI EF. Avaliação da qualidade de mudas de Eucalyptus grandis utilizando parâmetros morfológicos. Floresta (UFPR. Impresso), 2013, 43, 373-384.

Freitas, GA, Vaz de Melo A, PEREIRA, MAB, ANDRADE C AO, LUCENA GN, SILVA RR. Influência do sombreamento na qualidade de mudas de Sclerolobium paniculatum Vogel para recuperação de área degradada. Journal of Biotechnology and Biodiversity 2012, 3(3), 5-12.

Gonzaga LM, Silva SSS, Campos AS, Ferreira RP, Campos ANR, Cunha ACM. Recipientes e substratos para a produção de mudas de jatobá (Hymenaea courbaril L.). Revista Brasileira de Agropecuária Sustentável, 2016, 6(1), 64-73.

Gwenzi W, Nyambishi TJ, Chaukura N, Mapope N. Synthesis and nutrient release patterns of a biochar-based N-P-K slow-release fertilizer. Int. J. Environ. Sci. Technol. 2018, 15, 405-414.

Henderson, SM, Pabis S, Grain drying theory I: temperature effect on drying coefficient. Journal of Agricultural Engineering Research 1961, 6(3), 169-174.

Jadoski SO, Lopes EC, Maggi MF, Suchoronczek A, Saito LR, Denega S. Método de determinação da área foliar da cultivar de batata Ágata a partir de dimensões lineares. Ciências Agrárias. 2012, 33, 2545-2554.

Kratz D, Wendling I. Crescimento de mudas de Eucalyptus camaldulensis em substratos à base de casca de arroz carbonizada. Revista Ceres 2016, 63, 348-354.

Marschner, H. Mineral nutrition of higher plants. 3rd ed. London: Academic, 2012.

Mendes HSJ, Figueiredo PN, Scarpinatti, EA, Cesar PR. Respostas fisiológicas de genótipos de Eucalyptus grandis x E. urophylla à disponibilidade hídrica e adubação potássica. Cerne. 2013, 19, 603-611.

Mendonça V, Arruda NAA, Souza HÁ, Teixeira GA, Hafle OM, Ramos JD. Diferentes ambientes e osmocote na produção de mudas de tamarindeiro (Tamarindus indica). Ciência e Agrotecnologia 2008, 32, 391-397.

Muniz CO, Lôbo, LM, Fernandes FPR, Ferreira, EM, Brasil, EPF. Efeito de diferentes adubos NPK no processo de produção de mudas de eucalipto. Enciclopédia Biosfera, Centro Científico Conhecer, Goiânia, 2013, 9(17), 1162.

Navroski MC. et al. Efeito do volume do tubete e doses de fertilizantes no crescimento inicial de mudas de Eucalyptus dunnii Maiden. Agrarian 2016, 9, 26-33.

Oliveira AS, Neto AJS, Ribeiro A, Rascon NJL, Rody YP, Almeida AQ. Determinação do tempo térmico para o desenvolvimento de mudas de eucalipto na fase de enraizamento. Revista Brasileira de Engenharia Agrícola e Ambiental 2012, 16(11), 1223-1228.

Pinto SIC et al. Eficiência nutricional de clones de eucalipto na fase de mudas cultivados em solução nutritiva. Revista Brasileira de Ciência do Solo 2011, 35, 523-533.

Raymond JE, Fox, TR, Strahm, BD. Understanding the Fate of Applied Nitrogen in Pine Plantations of the Southeastern United States Using 15N Enriched Fertilizers. Forests. 2016, 7(12), 270

Reis AA. Substratos Orgânicos para produção de mudas de ubaia (Eugenia patrisii Vahl.) [Dissertação]. Jaboticabal Universidade Estadual Paulista -UNESP,2021.

Rossa UB, Camargo AA, Bognola IA, Westphalen DJ Milani JE. Fertilizante de liberação lenta no desenvolvimento de mudas de Eucalyptus grandis. Floresta 2015, 45, 85-97.

Rossa UB, Angeo AC, Nogueira, AC, Reissmann, CB, Grossi F, Ramos, M. R. Fertilizante de liberação lenta no crescimento de mudas de Araucaria angustifolia e Ocotea odorifera. Floresta 2011, 41(3), 491-500 2011.

Santos MERS, Bráulio MLS, Rocha GO, Freitas CAS, Silveira MCT, Souza DOC. Estrutura do dossel e características de perfilhos em pastos de capim-piatã manejados com doses de nitrogênio e períodos de diferimento variáveis. Zootecnia, ciência animal brasileira, 2017, 18, 1-13.

Silva, PHM, Poggiani F, Silva A A, Prada Neto I, Paula RC. Mortalidade, crescimento e solução do solo em eucalipto com aplicação de fertilizante de liberação lenta. Cerne, 2015, 21, 473-481.

Serrano, L. A. L.; Cattaneo, L. F.; Ferreguetti, G. A. Adubo de liberação lenta na produção de mudas de mamoeiro. Revista Brasileira de Fruticultura 2010, 32(3), 874-883.

Simão, L. A. Fertilizantes de liberação controlada no crescimento e desenvolvimento do mamoeiro 'THB [Dissertação] São Mateus: Universidade Federal do Espirito Santo, 2017.

Simões D, Silva RBG, Silva MR. Composição do substrato sobre o desenvolvimento, qualidade e custo de produção de mudas de Eucalyptus grandis Hill ex Maiden $\times$ Eucalyptus urophylla S. T. Blake. Ciência Florestal 2012, 22, 91-100.

Smiderle OJ, Souza AG, Chagas EA, Alves MS, Fagundes PRO. parâmetros de crescimento e curva de absorção de nutrientes de mudas de mogno africano com e sem solução nutritiva. 2018, Revista Brasileira de Agropecuária Sustentável, 8(4), 83-91

Steel RGD, Torrie JH. Principles and procedures of statistics. 2. ed. New York: McGraw-Hill, 1980. 
Trenkel, M. Slow- and controlled-release and stabilized fertilizers: an option for enhancing nutrient efficiency in agriculture. 2nd ed. Paris: International Fertilizer Industry Association, 2010. 163 p.

Xavier A, Wendling I, Silva RL. Silvicultura clonal: princípios e técnicas. Viçosa, MG: Universidade Federal de Viçosa; 2013.

Xiaoyu N, Yuejin W, Zhengyan W, Lin W, Guanna Q, Lixiang Y. A novel slow-release urea fertiliser: Physical and chemical analysis of its structure and study of its release mechanism. Biosystems engineering 2013, 115, 274-282.

Wendling I, Dutra LF. Produção de mudas de eucalipto por sementes. In: Wendling I Dutra LF. Produção de mudas de eucalipto. Colombo: Embrapa Florestas; 2010. p. 13-47.

Yamamoto CFEI et al. Slow release fertilizers based on urea/ureaFormaldehyde polymer nanocomposites. Chemical Engineering Journal 2016, 287, 390-397. 